\title{
Correction to: Peasant Farming, A Buffer for Human Societies
}

\author{
Angela Hilmi ${ }^{1}$ - Sara Burbi ${ }^{1}$
}

Published online: 31 October 2018

(C) Society for International Development 2018

Correction to: Development (2015) 58(2-3), 346-353 https://doi.org/10.1057/s41301-016-0035-z

Due to an unfortunate mistake, the authors' affiliation has been omitted. The affiliation is: Centre for Agroecology, Water and Resilience; Ryton-on-Dunsmore; UK
Centre for Agroecology, Water and Resilience (CAWR), Coventry University

Ryton Organic Gardens, Wolston Lane

Ryton-on-Dunsmore, Coventry, CV8 3LG, UK

We apologise for this mistake.

The original article can be found online at https:// doi.org/10.1057/s41301-016-0035-z.

$\bowtie$ Angela Hilmi

angela.hilmi@coventry.ac.uk

1 Centre for Agroecology, Water and Resilience (CAWR), Coventry University, Ryton Organic Gardens, Wolston Lane, Ryton-on-Dunsmore, Coventry CV8 3LG, UK 